\title{
Decreased striatal dopamine in group II metabotropic glutamate receptor (mGlu2/mGlu3) double knockout mice
}

\author{
Tracy A Lane ${ }^{1}$, Thomas Boerner ${ }^{1,2}$, David M Bannerman², James NC Kew ${ }^{3 \wedge}$, Elizabeth M Tunbridge ${ }^{1}$
} Trevor Sharp ${ }^{4}$ and Paul J Harrison ${ }^{1 *}$

\begin{abstract}
Background: Group II metabotropic glutamate receptors (mGlu2 and mGlu3, encoded by Grm2 and Grm3) have been the focus of attention as treatment targets for a number of psychiatric conditions. Double knockout mice

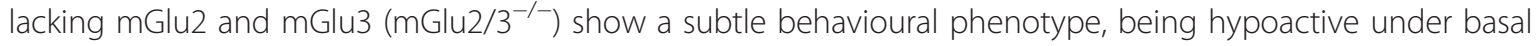
conditions and in response to amphetamine, and with a spatial memory deficit that depends on the arousal properties of the task. The neurochemical correlates of this profile are unknown. Here, we measured tissue levels of dopamine, $5-\mathrm{HT}$, noradrenaline and their metabolites in the striatum and frontal cortex of mGlu2/3 ${ }^{-/-}$double knockout mice, using high performance liquid chromatography. We also measured the same parameters in $\mathrm{mGlu}^{-/-}$and $\mathrm{mGlu}^{-/-}$ single knockout mice.
\end{abstract}

Results: $\mathrm{mGlu2} / \mathrm{3}^{-/}$mice had reduced dopamine levels in the striatum but not in frontal cortex, compared to wildtypes. In a separate cohort we replicated this deficit and, using tissue punches, found it was more prominent in the nucleus accumbens than in dorsolateral striatum. Noradrenaline, 5-HT and their metabolites were not altered in the striatum of mGlu2 $/ 3^{-/-}$mice, although the noradrenaline metabolite MHPG was increased in the cortex. In mGlu2 $2^{-/-}$ and $\mathrm{mGlu}^{-/-}$single knockout mice we found no difference in any monoamine or metabolite, in either brain region, compared to their wild-type littermates.

Conclusions: Group II metabotropic glutamate receptors impact upon striatal dopamine. The effect may contribute to the behavioural phenotype of $\mathrm{mGlu2} / 3^{-/-}$mice. The lack of dopaminergic alterations in $\mathrm{mGlu2} 2^{-1-}$ and $\mathrm{mGlu}^{-/-}$single knockout mice reveals a degree of redundancy between the two receptors. The findings support the possibility that interactions between mGlu2/3 and dopamine may be relevant to the pathophysiology and therapy of schizophrenia and other disorders.

Keywords: mGlu2, mGlu3, Grm2, Grm3, HPLC, Striatum, Nucleus accumbens

\section{Background}

Group II metabotropic glutamate receptors, mGlu2 and mGlu3, are G protein coupled receptors that negatively regulate adenylate cyclase [1]. The receptors are predominantly located pre-synaptically, where they function as auto- and hetero-receptors, inhibiting release of glutamate and other neurotransmitters, including dopamine. mGlu2 and mGlu3 are widely expressed in the

\footnotetext{
* Correspondence: paul.harrison@psych.ox.ac.uk

Deceased

'Department of Psychiatry, University of Oxford, Warneford Hospital, Oxford OX3 7JX, UK

Full list of author information is available at the end of the article
}

brain with overlapping but not identical regional, cellular, and subcellular distributions [2].

mGlu2 and mGlu3 have been implicated in a number of psychiatric disorders including, schizophrenia, addiction, anxiety and depression. In schizophrenia, for example, allelic variation in GRM3 (the gene encoding mGlu3) has been associated with disease risk, and mGlu2/3 agonists have shown efficacy in models of the disorder, and in one study, of the disorder itself [3-5]. However, the overall picture is complex, with studies showing varying results, and with uncertainty as to the pathways by which mGlu2/3 operate, including how they

\section{Biomed Central}


impact upon dopamine, the neurotransmitter central to existing treatments for schizophrenia.

Knockout mice lacking mGlu2 (mGlu2 ${ }^{-/-}$) or mGlu3 $\left(\mathrm{mGlu}^{-/-}\right)$have been generated to help characterize the function of these receptors. Results emphasize that the roles of these receptors are subtle, with the mice showing no overt behavioural or neurochemical phenotype at baseline [6-8]. This may in part be due to compensatory up-regulation of the remaining receptor [9]. Double knockout mice lacking both mGlu2 and mGlu3 (mGlu2/ $3^{-/-}$; also known as Grm2/3 $3^{-/-}$) show an emergent, and complex, phenotype. Specifically, the mice are hypoactive, are less sensitive to amphetamine induced hyperactivity, and have a spatial memory impairment in appetitive but not aversive tasks [10].

The neurochemical correlates of these behavioural findings are unknown, although the hypoactivity at baseline and in response to amphetamine are suggestive of alterations in dopamine and potentially of other monoamines. This is of relevance to the roles which group II mGlus may play in, or as targets for, dopamine-related psychiatric disorders. Here, we used high performance liquid chromatography (HPLC) to measure tissue levels of monoamines and their metabolites in the cortex and striatum of $\mathrm{mGlu} 2 / 3^{-1-}$ mice. Given the findings, we repeated the study in $\mathrm{mGlu} 2^{-/-}$and $\mathrm{mGlu}^{-/-}$single knockout mice, and also measured dopamine separately in the ventral striatum (nucleus accumbens [NAc]) and dorsolateral striatum of the $\mathrm{mGlu} 2 / 3^{-1-}$ mice.

\section{Results}

Tissue monoamine levels were measured in mGlu2/3 $3^{-/-}$ and wild-type mice. The main finding is a reduction in dopamine content in the striatum $(\sim 25 \%, \mathrm{p}=0.005)$, accompanied by similar reductions in the metabolites DOPAC $(\sim 28 \%, \mathrm{p}=0.004)$ and HVA $(\sim 22 \%, \mathrm{p}=0.023$; Figure 1$)$ of the $\mathrm{mGlu} 2 / 3^{-1-}$ mice. In addition, the noradrenaline metabolite MHPG was increased $(\sim 31 \%, \mathrm{p}=0.003)$ in frontal cortex (Table 1). There were no significant differences between groups in cortical dopamine metabolism, nor in 5-HT or its metabolite 5-HIAA in either region (Table 1). No significant interactions of sex and genotype were found.

The experiment was repeated in single $\mathrm{mGlu} 2^{-/-}$and mGlu3 ${ }^{-1-}$ knockout mice and their respective littermate controls. As detailed in Table 2, there were no differences in monoamines or their metabolites between genotypes. In particular, striatal dopamine showed no differences, nor trends.

To replicate and better characterize the striatal dopamine findings seen in the mGlu $2 / 3^{-/-}$mice, a second cohort of animals were studied, from which tissue micropunches were taken to allow separate measurements in dorsolateral striatum and NAc. Figure 2 shows that dopamine content

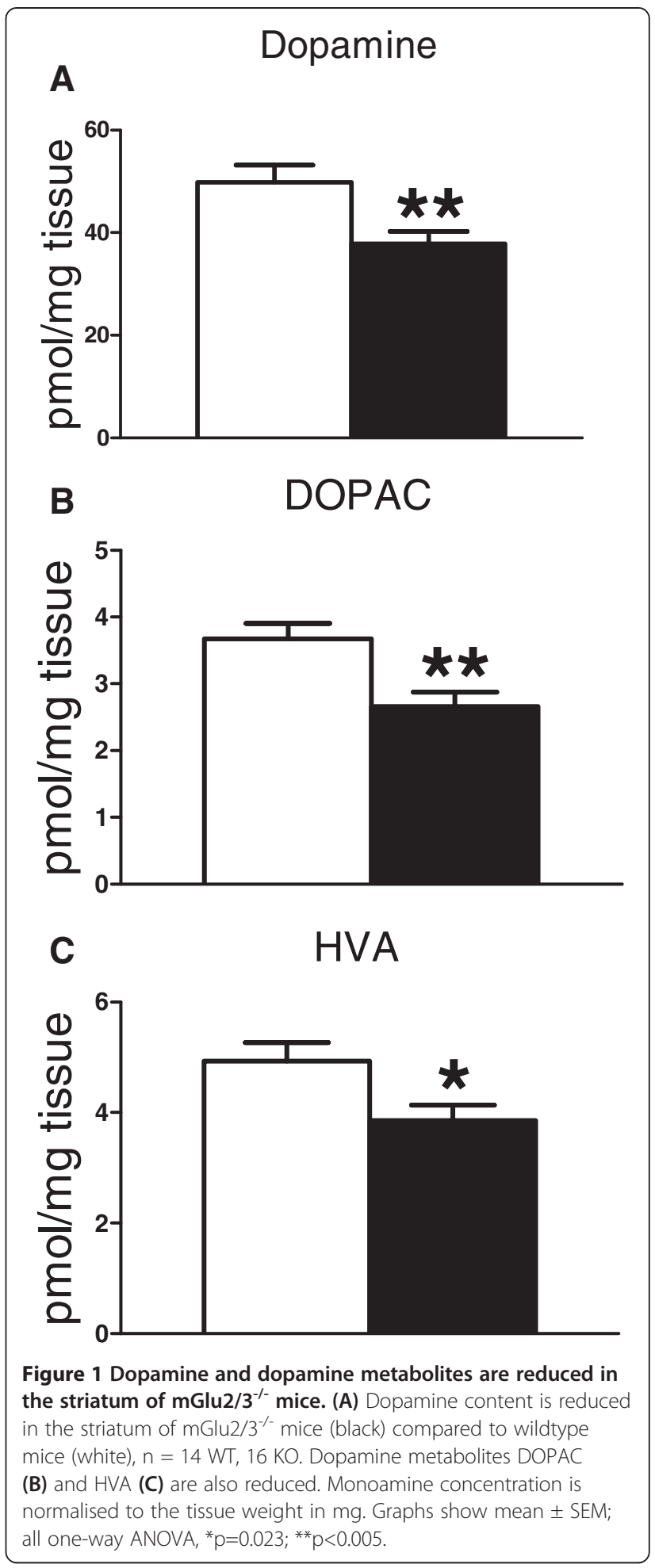

was decreased in NAc $(\sim 22 \%, \mathrm{p}=0.037)$ but not in the dorsolateral striatum $(\sim 6 \%, \mathrm{p}=0.837)$ of $\mathrm{mGlu} 2 / 3^{-/-}$mice. DOPAC followed a similar trend (NAc $\sim 25 \% \mathrm{p}=0.1$, and striatum $\sim 7 \%, \mathrm{p}=0.98$ ); HVA could not be measured in this experiment. 
Table 1 Monoamines and their metabolites in the cortex and striatum of $\mathrm{mGlu2/3^{-/- }}$ double knockout and wild-type (WT) mice

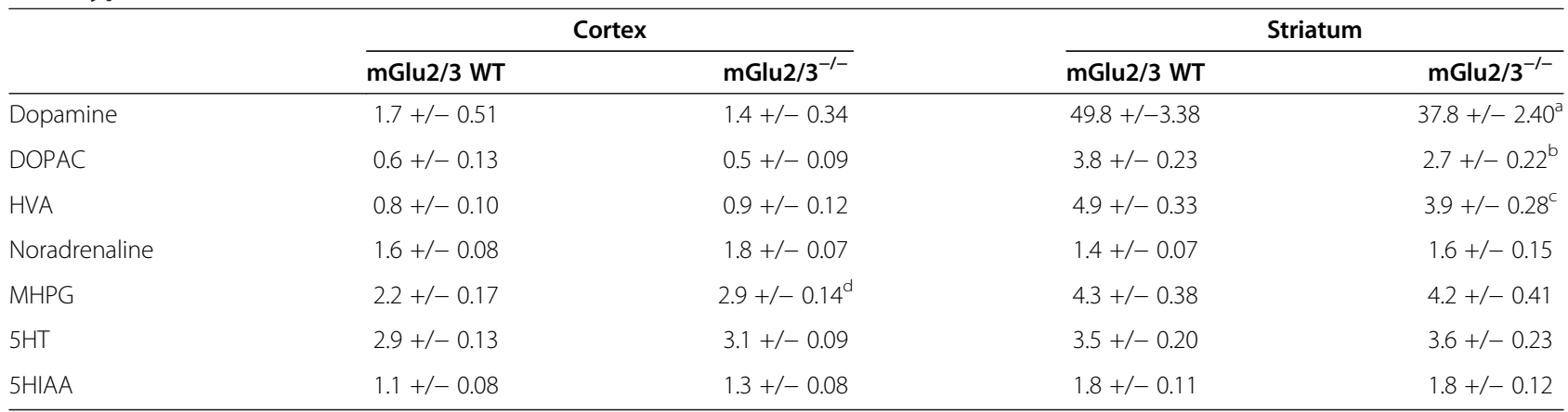

$\mathrm{n}=12-16 \mathrm{mGlu2} / 3^{-1-}$ mice, and 12-14 WT mice. Values are pmol/mg tissue, mean \pm SEM.

${ }^{\mathrm{a}} \mathrm{F} 1,26=9.25, \mathrm{p}=0.005$.

${ }^{\mathrm{b}} \mathrm{F} 1,26=9.85, \mathrm{p}=0.004$

${ }^{\mathrm{c}} \mathrm{F} 1,26=5.84, \mathrm{p}=0.023$.

${ }^{d} \mathrm{~F} 1,24=11.1, p=0.003$.

\section{Discussion}

Interactions between mGlu2/3 and monoamines, particularly dopamine, are of interest because of the putative roles of these receptors in the pathophysiology and therapy of various dopamine-related psychiatric disorders, including schizophrenia, anxiety, and addiction. The main finding of the present study is that deletion of both receptors leads to a decrease in striatal dopamine, particularly in the NAc. The data complement the many previous pharmacological studies which have shown effects of mGlu2/3 agonists and antagonists on dopamine, albeit with complex and in places inconsistent results [4,11-21].

Table 2 Monoamines and their metabolites in the cortex and striatum of $\mathrm{mGlu2}^{-1-}$ and $\mathrm{mGlu3}^{-1-}$ mice and their respective wild-type (WT) littermates

\begin{tabular}{|c|c|c|c|c|}
\hline & mGlu2 WT & mGlu2 $^{-/-}$ & mGlu3 WT & mGlu3 $^{-/-}$ \\
\hline & \multicolumn{4}{|c|}{ Cortex } \\
\hline Dopamine & $0.5+/-0.08$ & $0.4+/-0.07$ & $0.4+/-0.04$ & $0.4+/-0.05$ \\
\hline DOPAC & $0.2+/-0.03$ & $0.2+/-0.01$ & $0.2+/-0.02$ & $0.2+/-0.03$ \\
\hline Noradrenaline & $2.0+/-0.18$ & $1.8+/-0.16$ & $2.2+/-0.19$ & $2.3+/-0.22$ \\
\hline MHPG & $0.6+/-0.05$ & $0.6+/-0.05$ & $0.7+/-0.10$ & $0.8+/-0.07$ \\
\hline $5-\mathrm{HT}$ & $3.1+/-0.19$ & $3.1+/-0.23$ & $3.1+/-0.20$ & $2.9+/-0.25$ \\
\hline \multirow[t]{2}{*}{ 5-HIAA } & $1.0+/-0.03$ & $0.8+/-0.06$ & $0.8+/-0.08$ & $0.7+/-0.06$ \\
\hline & \multicolumn{4}{|c|}{ Striatum } \\
\hline Dopamine & $34.0+/-3.8$ & $36.5+/-3.8$ & $35.7+/-4.7$ & $32.6+/-3.3$ \\
\hline DOPAC & $2.3+/-0.2$ & $2.4+/-0.2$ & $2.1+/-0.1$ & $2.2+/-0.2$ \\
\hline HVA & $2.8+/-0.2$ & $3.1+/-0.2$ & $2.3+/-0.2$ & $3.0+/-0.3$ \\
\hline Noradrenaline & $2.0+/-0.2$ & $1.8+/-0.2$ & $1.5+/-0.1$ & $1.6+/-0.1$ \\
\hline $5-\mathrm{HT}$ & $2.9+/-0.2$ & $3.1+/-0.2$ & $3.6+/-0.2$ & $3.5+/-0.3$ \\
\hline 5-HIAA & $1.6+/-0.1$ & $1.6+/-0.1$ & $1.6+/-0.1$ & $1.8+/-0.03$ \\
\hline
\end{tabular}

$\mathrm{n}=6-8$ in each group. Values are $\mathrm{pmol} / \mathrm{mg}$ tissue, mean \pm SEM. There are no significant differences between groups. Reliable measurements for cortical HVA and striatal MHPG could not be obtained.
mGlu2 $/ 3^{-1-}$ mice are hypoactive and show decreased responsiveness to amphetamine [10]. It is plausible that the reduced dopamine 'tone' reported here contributes to these findings. Whether it also underlies the arousaldependent effect on spatial memory [10] or the impaired long-term depression [22] of the mice, is unknown. But it may be significant that the NAc is involved in motivation, reward and aversion [23,24]. Noradrenaline also plays a role in attention, arousal and stress [25] and mGlu2/3 ligands have been shown to regulate NA release [26]. We observed an increase in cortical MHPG and an increase in the MHPG to noradrenaline ratio $(p=0.053)$, which may reflect an increase in noradrenaline turnover and reduced pre-synaptic $\alpha 2$-adrenoceptor activity [27], therefore it is possible that changes in noradrenaline signalling are also important for the behavioural findings in these mice. In a future study, simultaneous behavioural and neurochemical measurements could be taken, helping to confirm and clarify the links between them, and could be extended to include other transmitters, such as GABA and glutamate.

We found no differences in monoamine content in either $\mathrm{mGlu}^{-1-}$ or $\mathrm{mGlu}^{-/-}$mice. In this respect the findings in the mGlu2 $/ 3^{-/-}$mice were emergent, and mirror the behavioural profile, which is present in the mGlu2 $/ 3^{-/-}$mice [10] but is not observed in either single knockout line [6-8,28-30] (and unpublished observations; De Filippis, DMB, PJH, TAL). One relevant finding in the $\mathrm{mGlu} 2^{-/-}$mice is that despite no changes in striatal tissue levels of dopamine (current data and [7]) and no baseline dialysate changes in glutamate or dopamine [7], these mice exhibit enhancement of cocaine-induced extracellular dopamine and glutamate in the NAc [7]. There is also evidence that a greater proportion of dopamine D2 receptors are in a high-affinity state in $\mathrm{mGlu}^{-/-}$ and $\mathrm{mGlu} 3^{-/}$mice, which may be indicative of a subtle difference in dopaminergic function [31]. By the same 

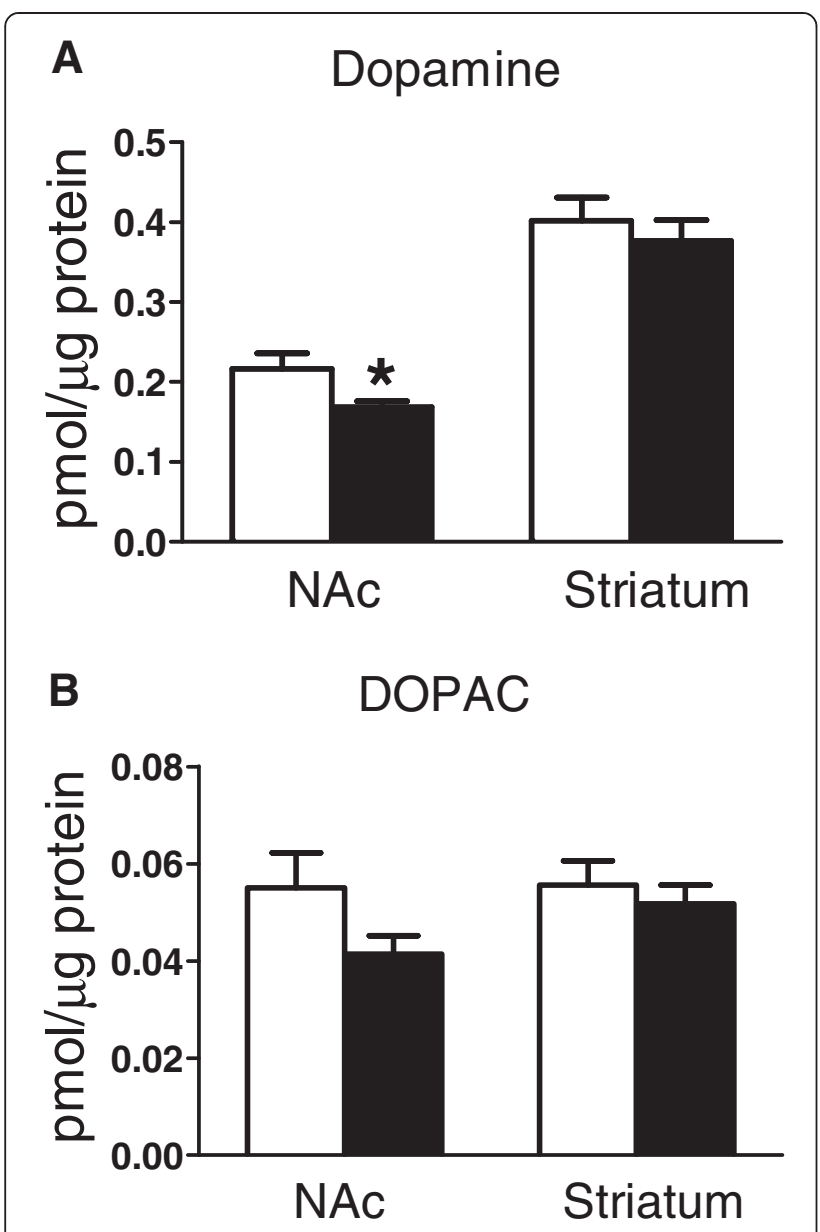

Figure 2 Dopamine is reduced in tissue punches of the NAC but not dorsolateral striatum of $\mathrm{mGlu} 2 / 3^{-/-}$mice. A: Dopamine content is reduced in tissue punches of NAc but not dorsolateral striatum of $\mathrm{mGlu} 2 / 3^{-/-}$mice (black) compared to wildtypes (white). $\mathrm{NAc} n=12 \mathrm{WT}, 12 \mathrm{KO}$ and dorsolateral striatum $\mathrm{n}=12 \mathrm{WT}, 14 \mathrm{KO}$. B: DOPAC shows a trend towards reduction in the NAc of mGlu2/ 3-/- mice $(p=0.1)$. NAc $n=12 \mathrm{WT}, 14 \mathrm{KO}$ and dorsolateral striatum $\mathrm{n}=12 \mathrm{WT}, 15 \mathrm{KO}$. Monoamine concentration is normalised to the total protein content of the punches. Graphs show mean \pm SEM; all one-way ANOVA except striatal DOPAC, analysed with Mann Whitney $U$ test, ${ }^{*} \mathrm{p}=0.037$.

token, the unchanged baseline levels of noradrenaline, 5 -HT and cortical dopamine in $\mathrm{mGlu} 2 / 3^{-/-}$mice reported here do not preclude the occurrence of functionally significant alterations in monoamine signalling.

The striatal dopamine deficit observed in the $\mathrm{mGlu} 2 / 3^{-/-}$ mice could be a result of reduced synthesis and storage, and/or decreased release. The latter explanation seems more likely given that dopamine and its metabolites were all comparably reduced. However, measurements of extracellular dopamine using microdialysis or voltammetry would be needed to confirm this interpretation.

There are a number of locations at which mGlu2/3 may regulate striatal dopamine, either directly or indirectly.
One possibility is that the receptors are expressed by, and function within, dopamine neurons. However, neither mGlu2 nor mGlu3 mRNA is detected in the substantia nigra pars compacta, while in the ventral tegmental area (VTA), only very low levels of mGlu2 and no mGlu3 mRNA is detected [32-34]. These data are complemented by findings that mGlu2/3 immunoreactivity does not colocalize with tyrosine hydroxylase positive axons in the striatum [35]. Similarly, there is little or no mGlu2/3 immunoreactivity detected in the VTA or substantia nigra pars compacta [35-37] suggesting that mGlu2/3 are unlikely to be located presynaptic to the dendrites or soma of dopamine neurons. This possibility cannot be excluded entirely since some data have shown functional mGlu2/3 receptors in VTA [38-40]. Nevertheless, together these results suggest that mGlu2/3 regulation of dopamine is not mediated by receptors expressed or located within the dopaminergic nuclei.

Instead, a more likely site for mGlu2/3-mediated modulation of striatal dopamine is within the striatum itself. The striatal neuropil shows strong mGlu2/3 immunoreactivity [2,35-37], accompanied by low to moderate levels of mGlu2 and mGlu3 mRNAs [32-34]. This combination of mRNA and protein data suggests that regulation of striatal dopamine by mGlu2/3 occurs via receptors which are expressed on the axonal processes of neurons projecting in from outside the striatum. Corticostriatal afferents are a strong candidate: mGlu2/3 immunoreactivity is present on their terminals $[37,41]$, striatal mGlu2/3 immunoreactivity is markedly decreased by decortication [35], and there is abundant mGlu2 and mGlu3 mRNA in cortical neurons [32,33,41]. Striatal mGlu2/3 are located at axo-dendritic synapses [42], ruling out direct effects on dopaminergic axon terminals. Thus, mGlu2/3 regulation of striatal dopamine is likely to be mediated via an intrinsic striatal neuron population that does not itself express mGlu2/3. This issue can be clarified by studies of the circuitry underlying the neurochemical results reported here. As part of this work, the possible contribution of glial mGlu3 should be considered $[2,35,43]$, and it will also be necessary to investigate the basis for the preferential reduction in dopamine in NAc versus dorsolateral striatum. Regarding the latter point, it might have been expected that the reduction in dopamine in the NAc (Figure 2) would have been of greater magnitude than that seen in the striatum overall (Figure 1). In the event, both were comparable (22-25\%). This may reflect the different methodologies and normalization methods used in the tissue punch and homogenisation experiments, or simply variation between cohorts.

As noted earlier, there have been many pharmacological studies showing that mGlu2/3 agonists and antagonists affect dopamine turnover, release and function 
[4,11-21]. In this respect our data are consistent with these findings. However, direct comparisons with the earlier pharmacological studies are difficult, for two reasons. Firstly, the most pertinent drug studies would be those using chronic administration of mGlu2/3 antagonists, yet to our knowledge these have not been conducted - the majority of studies have used agonists, and have used acute administration. Secondly, the pharmacological findings have been inconsistent, in terms of the magnitude and even the direction of effects on dopamine levels or release caused by acute administration of mGlu2/3 ligands [4,11-21]. Despite these issues, the present data support, and extend, the evidence that $\mathrm{mGlu} 2 / 3$ impact on dopamine, and thereby may be valuable therapeutic targets for disorders involving dopamine dysregulation.

\section{Conclusions}

Baseline tissue levels of dopamine and dopamine metabolites are reduced in the striatum of $\mathrm{mGlu} 2 / 3^{-1-}$ mice, providing novel evidence that group II metabotropic glutamate receptors influence the dopamine system. The finding is relevant to the development of $\mathrm{mGlu} 2 / 3$ ligands as potential therapies for neuropsychiatric disorders. No changes were observed in the frontal cortex, nor in mice lacking only one of the two receptors. The mechanisms by which $\mathrm{mGlu} 2 / 3^{-/-}$deletion results in decreased striatal dopamine (and whether it is a direct or indirect effect) are unknown. They may be clarified by dynamic measures of dopamine functioning, and by investigation of the molecular correlates of the neurochemical changes reported here.

\section{Methods}

All animal studies were carried out in accordance with Animals (Scientific Procedures) Act 1986 and the GSK Policy on the Care, Welfare and Treatment of Animals, and were approved by the relevant local ethics committee.

\section{Knockout mice}

mGlu2 (Grm2), mGlu3 (Grm3) single knockout (mGlu2 $2^{-/-}$ or $\mathrm{mGlu}^{-/-}$) and double knockout mice (mGlu2 $/ 3^{-/-}$) on a C57BL/6J background were obtained from GlaxoSmithKline, Harlow, U.K. The mGlu2 ${ }^{-/-}$mice were generated as in [30], $\mathrm{mGlu}^{-/-}$mice were generated as in [44] and $\mathrm{mGlu} 2 / 3^{-/-}$ were generated as in [10]. Briefly, $\mathrm{mGlu}^{-/-}$mice were crossed with $\mathrm{mGlu} 3^{-/-}$mice to generate double heterozygote offspring. Double heterozygotes were crossed to generate double knockout (1:16) and wild-type (WT; 1:16) mice. To avoid excessive animal wastage, separate lines of WT and $\mathrm{mGlu} 2 / 3^{-/-}$mice were established.

\section{Tissue preparation for homogenate studies}

Mice were culled by cervical dislocation. Frontal cortex and striatum were dissected out, snap frozen in isopentane on dry ice and stored at $-80^{\circ} \mathrm{C}$. For the study of mGlu $2 / 3^{-1-}$ mice, 16 double knockouts ( 8 male, 8 female) and 16 WT mice ( 8 male, 8 female), aged $8-11$ months, were used. For the studies of $\mathrm{mGlu} 2^{-/-}$and mGlu3 ${ }^{-/-}$mice, 8 males of each type were compared with 8 male littermate controls, aged 11-12 months. Final samples sizes were smaller for some analyses, either due to abnormal chromatograms, or due to outliers.

Immediately prior to HPLC analysis, tissue was removed from the freezer, weighed and homogenised in $0.06 \mathrm{M}$ perchloric acid (PCA) with a polytron homogeniser for 20 seconds. Samples were centrifuged for 5 minutes at $14,000 \mathrm{rpm}$ on a desktop centrifuge at $4^{\circ} \mathrm{C}$ and the supernatant collected and filtered (using a $13 \mathrm{~mm}$ syringe filter, Whatman). Samples were handled on ice and run as soon as possible to prevent degradation. Monoamine concentration was measured using HPLC and normalised to the tissue weight of each sample.

\section{Tissue preparation for tissue punch study}

$15 \mathrm{mGlu} 2 / 3^{-/-}$(8 male, 7 female), and $12 \mathrm{WT}$ (7 male, 5 female) mice, aged $6-11$ months, were culled by cervical dislocation and the whole brain snap frozen in liquid nitrogen and stored at $-80^{\circ} \mathrm{C}$. Coronal brain sections containing the NAc and striatum were cut on a cryostat (thick sections were produced by pressing the advance button 20 times before cutting each section), collected on untreated glass slides, and stored at $-80^{\circ} \mathrm{C}$.

Immediately prior to HPLC analysis, slides containing 2 to 3 brain sections for each mouse were placed on dry ice and two tissue punches from each hemisphere were taken, one from dorsolateral striatum and one from ventral striatum containing mostly NAc, resulting in a total of 4 punches per section. Approximately 8 punches per brain region per mouse were taken. A $0.5 \mathrm{~mm}$ diameter sample corer (Fine Science Tools 18035-50) was used to make the tissue punch. Punches were ejected into $200 \mu \mathrm{l}$ of ice cold $0.06 \mathrm{M}$ PCA, lysed by placing in an ice cold ultrasonic bath for $1 \mathrm{~min}$ and centrifuged at 13,000 rpm for $10 \mathrm{~min}$ in a desk top centrifuge at $4^{\circ} \mathrm{C}$. The supernatant was removed, filtered and analysed with HPLC. Protein pellets were collected and stored at $-80^{\circ} \mathrm{C}$. The total protein content in each sample was determined using Bradford assay; samples were diluted with $5 \mu \mathrm{l}$ of $1 \mathrm{M} \mathrm{NaOH}$, solubilised and $20 \mu \mathrm{l}$ of $\mathrm{ddH}_{2} \mathrm{O}$ added and then Bradford assay run as per standard protocol (Sigma, UK). Monoamine concentrations were normalised to the protein content as measured above.

\section{HPLC detection}

Immediately after filtration, levels of dopamine, noradrenaline, 5-HT, DOPAC, HVA, MHPG and 5-HIAA were measured using HPLC and electrochemical detection. Analytes were separated by injecting $50 \mu \mathrm{l}$ of sample 
into a Microsorb C18 column $(100 \times 4.6 \mathrm{~mm}$ column, $3 \mu \mathrm{m} \mathrm{C18} \mathrm{Microsorb} \mathrm{particles,} \mathrm{Varian} \mathrm{Inc)} \mathrm{and} \mathrm{a} \mathrm{mobile}$ phase containing $120 \mathrm{mM} \mathrm{NaH}_{2} \mathrm{PO}_{4}, 2 \mathrm{mM} \mathrm{NaCl}, 0.1 \mathrm{mM}$ EDTA, 2 mM OSA (1-Octanesulphonic acid sodium) and $15 \%(\mathrm{v} / \mathrm{v})$ methanol, $\mathrm{pH} 3.71$, at a flow rate of $1 \mathrm{ml} / \mathrm{min}$ (Jasco pump, Jasco, UK). Analytes were electrochemically detected using an ANTEC Decade II amperometric detector, (set at $28^{\circ} \mathrm{C}$ [first double knockout experiment]) or $36^{\circ} \mathrm{C}$ (single knockout and tissue punch experiments), Antec Leyden, Zoeterwoude, The Netherlands), which was equipped with an ISAAC flow cell (Antec Leyden, Zoeterwoude, The Netherlands) operated at $+0.6 \mathrm{~V}$ with an $\mathrm{Ag} / \mathrm{AgCl}$ reference electrode. Chromatograms were processed by ChromPass software (Jasco, UK).

\section{Data analysis}

We first checked for outliers, defined as being $>3 \times$ outside the interquartile range, and assessed data with the D'Agostino and Pearson omnibus K2 normality test. Where data were suitable for parametric analysis, we used one-way ANOVA with genotype and sex as dependent factors for the double knockout mice experiments, and t-tests for the single knockouts (since only males were studied). When data were not normally distributed, the Mann-Whitney $U$ test was used; in the event, the latter was required for analyses of cortical dopamine, DOPAC and 5-HIAA in the mGlu2 $/ 3^{-1-}$ mice, for cortical DA and 5-HT in mGlu2 ${ }^{-/-}$mice, and for striatal DOPAC in the tissue punch study. Analyses were conducted using SPSS v20 and Graphpad Prism 5. All tests were 2-tailed.

\section{Abbreviations \\ DOPAC: 3,4-Dihydroxyphenylacetic acid; MHPG: 3-Methoxy-4- hydroxyphenylglycol; 5-HIAA: 5-Hydroxyindoleacetic acid; HPLC: High performance liquid chromatography; HVA: Homovanillic acid; mGlu3 ${ }^{-1-}$ : mGlu3

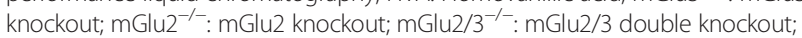 NAc: Nucleus accumbens; VTA: Ventral tegmental area; WT: Wild-type.}

\section{Competing interests}

JNCK was an employee of GlaxoSmithKline.

\section{Authors' contributions \\ PJH, DMB, JNCK, TAL designed the study. TAL and PJH drafted the manuscript. DMB, TS, EMT critically reviewed the manuscript. TAL carried out the study. TB helped with tissue punch experiments. EMT trained TAL in HPLC. TS supervised experiments. JNCK contributed reagents. All authors read and approved the final manuscript.}

\section{Acknowledgments}

This study was funded by Medical Research Council grant G0801747 to PJH TB holds a Lilly CASE Studentship award, supervised by DMB and PJH. We thank Corrado Corti, Declan Jones, Mikko Kaenmaki, Amy Taylor, and Mary Walker for their contributions. This paper is dedicated to the memory of James Kew.

\section{Author details}

'Department of Psychiatry, University of Oxford, Warneford Hospital, Oxford OX3 7JX, UK. ${ }^{2}$ Department of Experimental Psychology, University of Oxford, Oxford, UK. ${ }^{3}$ Neuroscience CEDD, GlaxoSmithKline, Harlow, UK. ${ }^{4}$ Department of Pharmacology, University of Oxford, Oxford, UK.
Received: 30 April 2013 Accepted: 17 September 2013

Published: 22 September 2013

\section{References}

1. Conn PJ, Pin JP: Pharmacology and functions of metabotropic glutamate receptors. Annu Rev Pharmacol Toxicol 1997, 37:205-237.

2. Petralia RS, Wang YX, Niedzielski AS, Wenthold RJ: The metabotropic glutamate receptors, mGluR2 and mGluR3, show unique postsynaptic, presynaptic and glial localizations. Neuroscience 1996, 71(4):949-976.

3. Harrison PJ, Lyon L, Sartorius LJ, Burnet PW, Lane TA: The group II metabotropic glutamate receptor 3 (mGluR3, mGlu3, GRM3): expression, function and involvement in schizophrenia. J Psychopharmacol 2008, 22(3):308-322.

4. Moghaddam B, Adams BW: Reversal of phencyclidine effects by a group II metabotropic glutamate receptor agonist in rats. Science 1998, 281(5381):1349-1352.

5. Patil ST, Zhang L, Martenyi F, Lowe SL, Jackson KA, Andreev BV, Avedisova AS, Bardenstein LM, Gurovich IY, Morozova MA, et al: Activation of mGlu2/3 receptors as a new approach to treat schizophrenia: a randomized Phase 2 clinical trial. Nat Med 2007, 13(9):1102-1107.

6. Fell MJ, Svensson KA, Johnson BG, Schoepp DD: Evidence for the role of metabotropic glutamate $(\mathrm{mGlu}) 2$ not $\mathrm{mGlu} 3$ receptors in the preclinical antipsychotic pharmacology of the $\mathrm{mGlu2} / 3$ receptor agonist (-)-(1R,4S,5S,6S)-4-amino-2-sulfonylbicyclo[3.1.0] hexane-4,6-dicarboxylic acid (LY404039). J Pharmacol Exp Ther 2008, 326(1):209-217.

7. Morishima Y, Miyakawa T, Furuyashiki T, Tanaka Y, Mizuma H, Nakanishi S: Enhanced cocaine responsiveness and impaired motor coordination in metabotropic glutamate receptor subtype 2 knockout mice. Proc Natl Acad Sci U S A 2005, 102(11):4170-4175.

8. Woolley ML, Pemberton DJ, Bate S, Corti C, Jones DN: The mGlu2 but not the mGlu3 receptor mediates the actions of the $\mathrm{mGluR2} / 3$ agonist, LY379268, in mouse models predictive of antipsychotic activity. Psychopharmacology (Berl) 2008, 196(3):431-440.

9. Lyon L, Kew JN, Corti C, Harrison PJ, Burnet PW: Altered hippocampal expression of glutamate receptors and transporters in GRM2 and GRM3 knockout mice. Synapse 2008, 62(11):842-850.

10. Lyon L, Burnet PW, Kew JN, Corti C, Rawlins JN, Lane T, De Filippis B, Harrison PJ, Bannerman DM: Fractionation of spatial memory in GRM2/3 (mGlu2/mGlu3) double knockout mice reveals a role for group II metabotropic glutamate receptors at the interface between arousal and cognition. Neuropsychopharmacology 2011, 36(13):2616-2628.

11. Cartmell J, Perry KW, Salhoff CR, Monn JA, Schoepp DD: The potent, selective $\mathrm{mGlu2} / 3$ receptor agonist LY379268 increases extracellular levels of dopamine, 3,4-dihydroxyphenylacetic acid, homovanillic acid, and 5-hydroxyindole-3-acetic acid in the medial prefrontal cortex of the freely moving rat. J Neurochem 2000, 75(3):1147-1154.

12. Cartmell J, Perry KW, Salhoff CR, Monn JA, Schoepp DD: Acute increases in monoamine release in the rat prefrontal cortex by the mGlu2/3 agonist LY379268 are similar in profile to risperidone, not locally mediated, and can be elicited in the presence of uptake blockade. Neuropharmacology 2001, 40(7):847-855.

13. Cartmell J, Salhoff CR, Perry KW, Monn JA, Schoepp DD: Dopamine and 5HT turnover are increased by the mGlu2/3 receptor agonist LY379268 in rat medial prefrontal cortex, nucleus accumbens and striatum. Brain Res 2000, 887(2):378-384.

14. Chaki S, Yoshikawa R, Okuyama S: Group II metabotropic glutamate receptor-mediated regulation of dopamine release from slices of rat nucleus accumbens. Neurosci Lett 2006, 404(1-2):182-186.

15. D'Souza MS, Liechti ME, Ramirez-Nino AM, Kuczenski R, Markou A: The metabotropic glutamate 2/3 receptor agonist LY379268 blocked nicotine-induced increases in nucleus accumbens shell dopamine only in the presence of a nicotine-associated context in rats. Neuropsychopharmacology 2011, 36(10):2111-2124.

16. Greenslade RG, Mitchell SN: Selective action of (-)-2-oxa-4-aminobicyclo [3.1.0]hexane-4,6-dicarboxylate (LY379268), a group II metabotropic glutamate receptor agonist, on basal and phencyclidine-induced dopamine release in the nucleus accumbens shell. Neuropharmacology 2004, 47(1):1-8.

17. Hu G, Duffy P, Swanson C, Ghasemzadeh MB, Kalivas PW: The regulation of dopamine transmission by metabotropic glutamate receptors. $J$ Pharmacol Exp Ther 1999, 289(1):412-416. 
18. Karasawa J, Yoshimizu T, Chaki S: A metabotropic glutamate $2 / 3$ receptor antagonist, MGS0039, increases extracellular dopamine levels in the nucleus accumbens shell. Neurosci Lett 2006, 393(2-3):127-130.

19. Lorrain DS, Baccei CS, Bristow $\sqcup$, Anderson JJ, Varney MA: Effects of ketamine and $\mathrm{N}$-methyl-D-aspartate on glutamate and dopamine release in the rat prefrontal cortex: modulation by a group II selective metabotropic glutamate receptor agonist LY379268. Neuroscience 2003, 117(3):697-706

20. Pehrson AL, Moghaddam B: Impact of metabotropic glutamate $2 / 3$ receptor stimulation on activated dopamine release and locomotion. Psychopharmacology (Berl) 2010, 211(4):443-455.

21. Rorick-Kehn LM, Johnson BG, Knitowski KM, Salhoff CR, Witkin JM, Perry KW, Griffey Kl, Tizzano JP, Monn JA, McKinzie DL, et al: In vivo pharmacological characterization of the structurally novel, potent, selective mGlu2/3 receptor agonist LY404039 in animal models of psychiatric disorders. Psychopharmacology (Berl) 2007, 193(1):121-136.

22. Lyon L, Borel M, Carrion M, Kew JN, Corti C, Harrison PJ, Burnet PW, Paulsen $\mathrm{O}$, Rodriguez-Moreno A: Hippocampal mossy fiber long-term depression in Grm2/3 double knockout mice. Synapse 2011, 65(9):945-954.

23. Ikemoto S: Dopamine reward circuitry: two projection systems from the ventral midbrain to the nucleus accumbens-olfactory tubercle complex. Brain Res Rev 2007, 56(1):27-78.

24. Lammel S, Lim BK, Ran C, Huang KW, Betley MJ, Tye KM, Deisseroth K, Malenka RC: Input-specific control of reward and aversion in the ventral tegmental area. Nature 2012, 491(7423):212-217.

25. Arnsten AF: Catecholamine influences on dorsolateral prefrontal cortical networks. Biol Psychiatry 2011, 69(12):e89-99.

26. Lorrain DS, Schaffhauser H, Campbell UC, Baccei CS, Correa LD, Rowe B, Rodriguez DE, Anderson JJ, Varney MA, Pinkerton AB, et al: Group II mGlu receptor activation suppresses norepinephrine release in the ventral hippocampus and locomotor responses to acute ketamine challenge. Neuropsychopharmacology 2003, 28(9):1622-1632.

27. Heal DJ, Prow MR, Buckett WR: Measurement of 3-methoxy-4hydroxyphenylglycol (MHPG) in mouse brain by h.p.l.c. with electrochemical detection, as an index of noradrenaline utilisation and presynaptic alpha 2-adrenoceptor function. Br J Pharmacol 1989, 96(3):547-556

28. Higgins GA, Ballard TM, Kew JN, Richards JG, Kemp JA, Adam G, Woltering T, Nakanishi S, Mutel V: Pharmacological manipulation of $m G l u 2$ receptors influences cognitive performance in the rodent. Neuropharmacology 2004, 46(7):907-917.

29. Linden AM, Shannon H, Baez M, Yu JL, Koester A, Schoepp DD: Anxiolyticlike activity of the $\mathrm{mGLU} 2 / 3$ receptor agonist LY354740 in the elevated plus maze test is disrupted in metabotropic glutamate receptor 2 and 3 knock-out mice. Psychopharmacology (Berl) 2005, 179(1):284-291.

30. Yokoi M, Kobayashi K, Manabe T, Takahashi T, Sakaguchi I, Katsuura G, Shigemoto R, Ohishi H, Nomura S, Nakamura K, et al: Impairment of hippocampal mossy fiber LTD in mice lacking mGluR2. Science 1996, 273(5275):645-647.

31. Seeman P, Battaglia G, Corti C, Corsi M, Brun V: Glutamate Receptor mGlu2 and mGlu3 Knockout Striata are Dopamine Supersensitive, With Elevated D2(High) Receptors and Marked Supersensitivity to the Dopamine Agonist (+)PHNO. Synapse 2009, 63(3):247-251.

32. Ohishi H, Shigemoto R, Nakanishi S, Mizuno N: Distribution of the mRNA for a metabotropic glutamate receptor (mGluR3) in the rat brain: an in situ hybridization study. J Comp Neurol 1993, 335(2):252-266.

33. Ohishi H, Shigemoto R, Nakanishi S, Mizuno N: Distribution of the messenger RNA for a metabotropic glutamate receptor, mGluR2, in the central nervous system of the rat. Neuroscience 1993, 53(4):1009-1018.

34. Testa CM, Standaert DG, Young AB, Penney JB Jr: Metabotropic glutamate receptor mRNA expression in the basal ganglia of the rat. $J$ Neurosci 1994, 14(5 Pt 2):3005-3018.

35. Testa CM, Friberg IK, Weiss SW, Standaert DG: Immunohistochemical localization of metabotropic glutamate receptors mGluR1a and mGluR2/ 3 in the rat basal ganglia. J Comp Neurol 1998, 390(1):5-19.

36. Ohishi $H$, Neki A, Mizuno N: Distribution of a metabotropic glutamate receptor, mGluR2, in the central nervous system of the rat and mouse: an immunohistochemical study with a monoclonal antibody. Neurosci Res 1998, 30(1):65-82.

37. Tamaru Y, Nomura S, Mizuno N, Shigemoto R: Distribution of metabotropic glutamate receptor mGluR3 in the mouse CNS: differential location relative to pre- and postsynaptic sites. Neuroscience 2001, 106(3):481-503.

38. Hao Y, Martin-Fardon R, Weiss F: Behavioral and functional evidence of metabotropic glutamate receptor $2 / 3$ and metabotropic glutamate receptor 5 dysregulation in cocaine-escalated rats: factor in the transition to dependence. Biol Psychiatry 2010, 68(3):240-248.

39. Liechti ME, Lhuillier L, Kaupmann K, Markou A: Metabotropic glutamate 2/3 receptors in the ventral tegmental area and the nucleus accumbens shell are involved in behaviors relating to nicotine dependence. J Neurosci 2007, 27(34):9077-9085.

40. Xi ZX, Ramamoorthy S, Baker DA, Shen H, Samuvel DJ, Kalivas PW: Modulation of group II metabotropic glutamate receptor signaling by chronic cocaine. J Pharmacol Exp Ther 2002, 303(2):608-615.

41. Gu G, Lorrain DS, Wei H, Cole RL, Zhang X, Daggett LP, Schaffhauser HJ, Bristow $L$, Lechner SM: Distribution of metabotropic glutamate 2 and 3 receptors in the rat forebrain: Implication in emotional responses and central disinhibition. Brain Res 2008, 1197:47-62.

42. Robbe D, Alonso G, Chaumont S, Bockaert J, Manzoni OJ: Role of p/q-Ca2+ channels in metabotropic glutamate receptor 2/3-dependent presynaptic long-term depression at nucleus accumbens synapses. J Neurosci 2002, 22(11):4346-4356.

43. Xi ZX, Baker DA, Shen H, Carson DS, Kalivas PW: Group II metabotropic glutamate receptors modulate extracellular glutamate in the nucleus accumbens. J Pharmacol Exp Ther 2002, 300(1):162-171.

44. Corti C, Battaglia G, Molinaro G, Riozzi B, Pittaluga A, Corsi M, Mugnaini M, Nicoletti F, Bruno V: The use of knock-out mice unravels distinct roles for mGlu2 and mGlu3 metabotropic glutamate receptors in mechanisms of neurodegeneration/neuroprotection. J Neurosci 2007, 27(31):8297-8308.

doi:10.1186/1471-2202-14-102

Cite this article as: Lane et al:: Decreased striatal dopamine in group II metabotropic glutamate receptor (mGlu2/mGlu3) double knockout mice. BMC Neuroscience 2013 14:102.

\section{Submit your next manuscript to BioMed Central and take full advantage of:}

- Convenient online submission

- Thorough peer review

- No space constraints or color figure charges

- Immediate publication on acceptance

- Inclusion in PubMed, CAS, Scopus and Google Scholar

- Research which is freely available for redistribution

Submit your manuscript at www.biomedcentral.com/submit
C) Biomed Central 